\title{
Molecular characterization of birnaviruses isolated from wild marine fishes at the Flemish Cap (Newfoundland)
}

\author{
I. Romero-Brey ${ }^{1}$, W.N. Batts ${ }^{2}$, I. Bandín ${ }^{1}$, J.R. Winton ${ }^{2}$, C.P. Dopazo ${ }^{1, *}$ \\ ${ }^{1}$ Unidade de Ictiopatoloxía, Departamento de Microbioloxía e Parasitoloxía, Instituto de Acuicultura, \\ Universidade de Santiago de Compostela, 15782 Santiago de Compostela, Spain \\ ${ }^{2}$ Western Fisheries Research Center, United States Geological Survey, 6505 NE 65th St., Seattle, Washington 98115, USA
}

\begin{abstract}
Several isolates of aquatic birnaviruses were recovered from different species of wild fish caught in the Flemish Cap, a Newfoundland fishery close to the Atlantic coast of Canada. The nucleotide sequence of a region of the NS gene was identical among the isolates and was most similar to the Dry Mills and West Buxton reference strains of infectious pancreatic necrosis virus (IPNV). Phylogenetic analysis of the sequence of a region of the VP2 gene demonstrated that the isolates were most closely aligned with the American strains of IPNV serotype A1. Electron microscopy of virus structures clarified and concentrated from cultures of infected chinook salmon embryo (CHSE214) cells revealed a majority of typical IPNV-like icosahedral particles, as well as a low proportion of type I tubules having a diameter of approximately $55 \mathrm{~nm}$ and a variable length of up to $2 \mu \mathrm{m}$. The tubules could be propagated in cell cultures, but always in the presence of low proportions of icosahedral particles. Cloning of selected isolates by serial dilution yielded preparations with a high proportion of the tubular structures with a density in $\mathrm{CsCl}$ gradients of approximately $1.30 \mathrm{~g} \mathrm{~cm}^{-3}$. Polyacrylamide gel electrophoresis revealed the material in the band was composed of the IPNV pVP2 and VP2 proteins.
\end{abstract}

KEY WORDS: Wild fishes · Birnavirus $\cdot$ Aquabirnavirus $\cdot$ IPNV

\section{INTRODUCTION}

Infectious pancreatic necrosis virus (IPNV) is the type species of the Aquabirnavirus genus of the family Birnaviridae (van Regenmortel et al. 2000). This family of single-shelled, non-enveloped, icosahedral viruses, so called because their genome consist of 2 segments of double-stranded RNA (Dobos et al. 1979), also includes infectious bursal disease virus (IBDV) of domestic fowl (Müller et al. 1979) and Drosophila X virus of Drosophila melanogaster (Teninges et al. 1979).

As one of the most important viral pathogens of trout and salmon, highly virulent strains of IPNV can cause greater than $90 \%$ mortality in fry less than 4 mo of age. Survivors of infection may remain life-long asympto- matic carriers and can serve as reservoirs of infection (McAllister et al. 1987).

The genome of IPNV consists of 2 segments of double-stranded RNA that are surrounded by a singleshelled icosahedral capsid of 60 to $65 \mathrm{~nm}$ in diameter (Dobos 1976). The larger genome segment A (3.2 kb) contains 2 partially overlapping open reading frames (ORFs). The largest encodes a $106 \mathrm{kDa}$ polyprotein (5'-pVP2-NS-VP3-3'), which is co-translationally cleaved by the viral nonstructural (NS or VP4; $29 \mathrm{kDa}$ ) protease to generate pVP2 (63 kDa) and VP3 (29 to $31 \mathrm{kDa}$ ) proteins (Huang et al. 1986, Duncan et al. 1987, Nagy et al. 1987). The pVP2 is processed into the mature 50-55 kDa VP2 (Manning \& Leong 1990). Both VP2 and VP3 are major components of the virion, while VP4 is present in smaller amounts. Major neutralizing 
epitopes are carried on VP2, suggesting that it is at least partly exposed in the outer surface of the capsid; this protein is glycosylated in the virion and freely in the cytoplasm (Hjalmarsson et al. 1999, Espinoza et al. 2000). The VP3 contains a very basic carboxy-terminal region, which is likely to interact with the packaged RNA and, therefore, believed to be inside the capsid. Segment A also encodes a $17 \mathrm{kDa}$ arginine-rich NS protein (VP5) from a small ORF, which precedes and partially overlaps the major polyprotein ORF (Håvarstein at al. 1990). Although this protein is not present in the virion, it is detected in IPNV-infected cells (Magyar \& Dobos 1994) and it could be involved in the regulation of the host apoptosis-off system for enhancing progeny production (Hong et al. 2002). The smaller genome segment $B(2.9 \mathrm{~kb})$ contains one ORF that encodes VP1, a protein of 90 to $110 \mathrm{kDa}$ considered to be an RNA-dependent RNA polymerase $(\mathrm{RdRp})$ responsible for the replication and transcription of the viral genome.

Preparations of purified IPNV virions have been reported to contain both full and empty icosahedral virions as well as tubules having a diameter of approximately $50 \mathrm{~nm}$ (type I), made up of regularly repeated subunits and composed mainly of pVP2 (Granzow et al. 1997b, Crane et al. 2000, Espinoza et al. 2000). However, the origin and function of these tubules is still unknown. Whereas type I tubules were observed in cells infected by members of all genera of Birnaviridae (Teninges et al. 1979, Schwanz-Pfitzner et al. 1984, Özel \& Gelderblom 1985), type II tubules, which contain VP4, were only detected in cells infected with IBDV or in purified IBDV preparations (Granzow et al. 1997a).

Most aquatic birnaviruses, regardless of host species or geographic origin, are antigenically related and are members of a single large serogroup A (Caswell-Reno et al. 1989, Christie et al. 1990, Nicholson 1993). A relatively few antigenically unrelated aquatic birnaviruses are members of a second, minor serogroup B. On the basis of reciprocal neutralization tests with polyclonal antisera and enzyme immunoassays with monoclonal antibodies, serogroup A has been demonstrated to contain 9 serotypes, named A1 to A9 (Hill \& Way 1995). The A1 serotype includes most of the isolates from the United States (reference strain West Buxton [WB]). Four serotypes (A6 to A9) occur in Canada (reference strains C1, C2, C3, and Jasper [Ja]), while the remaining 4 serotypes (A2 to A5) are found principally in Europe (reference strains $\mathrm{Sp}, \mathrm{Ab}$, Hecht
[He] and Tellina [Te], respectively). Isolates related to the Ab, Sp or WB types have also been found in Asia and South America.

In the summers of 1994 and 1999, our laboratory collected tissues samples from marine fishes at the Flemish Cap (Newfoundland). During the FC'99 oceanographic campaign, most of the viruses isolated were identified as birnavirus-like viruses but, interestingly, electron microscopy revealed the presence of tubular structures together with icosahedral virus-like particles (Romero-Brey et al. 2002). In this study, we sought to further characterize and to compare these isolates, as well as to determine the nature and composition of the tubules.

\section{MATERIALS AND METHODS}

Viruses and cells. The birnavirus isolates characterized in the present study were as follows: $19 \mathrm{~F} 3_{\mathrm{A}}, 19 \mathrm{~F} 3_{\mathrm{B}}$ and 20F2, recovered from Greenland halibut (Reindhartius hippoglossoides); $5 \mathrm{~B} 1_{\mathrm{D}}$ and $6 \mathrm{~B} 1_{\mathrm{D}}$, from Atlantic cod (Gadus morhua); 9R3, from onion-eye grenadier (Macrourus berglax); 17R5, from Atlantic wolf-fish (Anarhichas lupus); and 19G5, from deepwater redfish (Sebastes mentella). All isolates were propagated at $15^{\circ} \mathrm{C}$ in chinook salmon embryo (CHSE-214) cell cultures (Lannan et al. 1984) using Eagle's minimum essential medium (EMEM) containing 10\% fetal bovine serum (FBS). The EPC (epithelioma papillosum cyprini) cell line was also used for protein and Western blot analysis. Cloning of viral isolates was performed by inoculation of serial dilutions onto 96-well plates of CHSE-214 cells, using 15 wells per dilution.

RT-PCR amplification. Primer sequences are shown in Table 1 and their relative positions on the IPNV segment A are shown in Fig. 1. Primer set Pr D, described

Table 1. Description of primers used for identification and sequence analysis of the birnavirus isolates

\begin{tabular}{|c|c|c|}
\hline Primer & Primer sequence & $\begin{array}{l}\text { Primer } \\
\text { position }^{b}\end{array}$ \\
\hline $\mathrm{D}_{1}{ }^{\mathrm{a}}$ & 5'-AAAGCCATAGCCGCCCATGAAC-3' & $2139-2160$ \\
\hline $\mathrm{D}_{2}^{\mathrm{a}}$ & 5'-TCTCATCAGCTGGCCCAGGTAC-3' & $2312-2291$ \\
\hline $\mathrm{IB}_{1}$ & 5'-ACCAAGACCAACTCAGC-3' & $1563-1579$ \\
\hline $\mathrm{IB}_{2}$ & 5'-GCAGCTGGAGGCCGCTA-3' & $1602-1618$ \\
\hline $\mathrm{IB}_{3-}$ & 5'-CTCGTCGACCCCTGGTTG-3' & $2201-2184$ \\
\hline $\mathrm{IB}_{\mathrm{VP} 2 \mathrm{ext}+}$ & 5'-GGGTTTGACAAGCCATACGT-3' & $624-643$ \\
\hline $\mathrm{IB}_{\mathrm{VP} 2 \text { ext- }}$ & 5'-TTGGATACGCCGGCCACGGT-3' & $1231-1212$ \\
\hline $\mathrm{IB}_{\mathrm{VP} 2 \mathrm{int}+}$ & 5'-TACGAAATAGACCTCCCATC-3' & $729-748$ \\
\hline $\mathrm{IB}_{\mathrm{VP} 2 \text { int }-}$ & 5'-ACCCCCGGCACATTGCCATT-3' & $1156-1137$ \\
\hline \multicolumn{3}{|c|}{$\begin{array}{l}\text { aAs described by Blake et al. (1995) } \\
\text { bMap position of the primers based on the published sequence of Jasper } \\
\text { strain (Duncan \& Dobos 1986) (GenBank \# M18049) }\end{array}$} \\
\hline
\end{tabular}




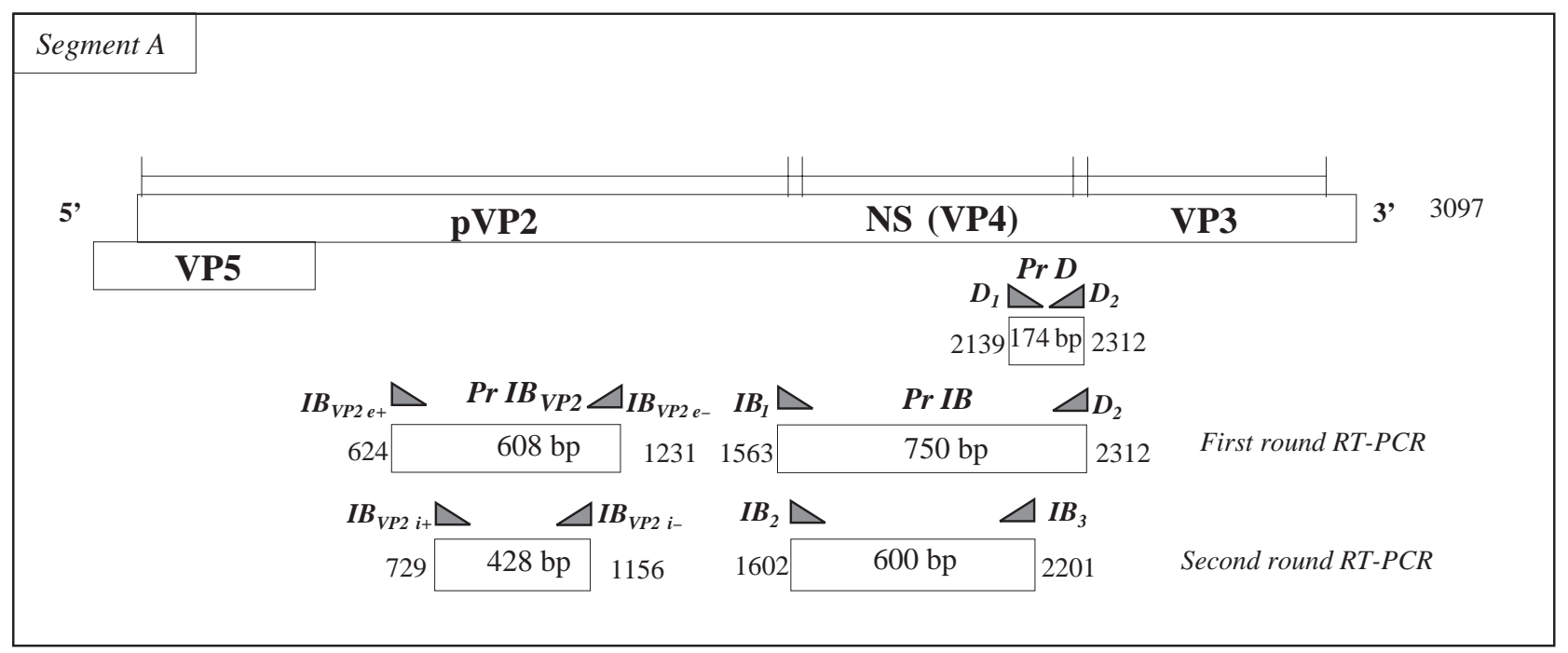

Fig. 1. Map of the genome segment A with the relative locations of the target sequences for primer sets Pr D, Pr IB and Pr IB $\mathrm{VP2}$ according to the published sequence of Jasper strain (Duncan \& Dobos 1986, Dobos 1995) (GenBank \# M18049)

by Blake et al. (1995), was used to confirm that the isolates under study were aquatic birnaviruses. Primer sets Pr IB and Pr IB $\mathrm{VP}_{\mathrm{VP}}$, employed for sequencing, were selected on the basis of published sequences of the genome segment A of the West Buxton (GenBank \# AF342727) and Dry Mills (GenBank \# AF343571) strains (Blake et al. 2001). In addition, to amplify a sufficient quantity of DNA for direct sequencing, we designed a nested-PCR using 2 pairs of primers (external and internal).

Release of viral RNA and RT-PCR amplification was performed as previously reported by Huang et al. (1996), with slight modifications: $100^{\circ} \mathrm{C}$ for $10 \mathrm{~min}$ instead of $95^{\circ} \mathrm{C}$ for 2 min for the release of RNA, and using 30 cycles instead of 25 in the nested PCR.

PCR products $(10 \mathrm{ml})$ were analyzed on $1.5-2 \%$ agarose DNA Grade gels (Fisher Scientific) in TBE buffer (0.89 M Tris, 0.89 M Boric acid, 0.02 M EDTA) at $200 \mathrm{~V}$ for $45 \mathrm{~min}$. The gels were stained with ethidium bromide and visualized under UV light.

DNA sequencing and sequence analysis. Prior to sequencing, the PCR products were purified using the commercial StrataPrep ${ }^{\mathrm{TM}}$ PCR Purification kit (Stratagene), following the protocol described by the manufacturer. The purified PCR products were sequenced using Taq polymerase-mediated incorporation of dyelabeled dideoxy terminators (ABIPrism' Big Dye ${ }^{\mathrm{TM}}$ Terminator, Cycle Sequencing Ready Reaction Kit). The labelling reaction mixture was purified using SpinColumns (Sephadex ${ }^{\mathrm{TM}}$ G-50 Medium, Amersham Pharmacia Biotech AB). The sample was dried in a vacuum centrifuge, resuspended in $25 \mu$ l of TSR (Template Supression Reagent, Applied Biosystems) and sub- jected to sequencing in an ABI Prism 310 Genetic Analyzer (Perkin Elmer). The sequences were obtained by a 310 Data Collection Software, version 3.0, and edited using the Sequence Navigator (Applied Biosystems) program. Deduced amino acid sequences were derived with the DNASTAR (Lasergene) EditSeq computer program. Multiple sequence alignments were performed using DNASTAR (Lasergene) MegAlign program, with suggested parameters of Unweighted Gap penalty of 10 and Gap length penalty of 10. Phylogenetic trees were constructed with the MegAlign program, using a Clustal algorithm. Apart from the main serotypes of IPNV, the marine birnaviruses yellowtail ascites virus (YAV) and blotched snakehead virus (BSV), as well as IBDV, were included with comparative purposes.

Viral nucleic acid analysis. Analysis of genomic electropherotypes was performed as previously described by Cutrín et al. (2000). Reference strains of IPNV Ab, Sp, WB, C1, C2 and Ja were used as controls. Viral RNA from the aquareovirus HBR was included as a molecular weight marker (Dopazo et al. 1992).

Protein analysis. Supernatant fluids from CHSE-214 and EPC cell cultures exhibiting a cytopathic effect (CPE) were collected and centrifuged for $30 \mathrm{~min}$ at $1500 \times g$. The supernatants were ultracentrifuged for $90 \mathrm{~min}$ at $90000 \times g$ and the pellets resupended in $100 \mathrm{ml}$ of sample buffer (20 mM Tris- $\mathrm{HCl}, 5$ mM EDTA, $1 \mathrm{M} \mathrm{NaCl}$ ). Culture fluid from uninfected cells was also included as a negative control.

Viral proteins were analysed by SDS-polyacrylamide gel electrophoresis (SDS-PAGE) according to the method of Laemmli (1970) using a 12\% polyacry- 
lamide gel in a Mini-PROTEAN ${ }^{\circledR}$ II vertical gel electrophoresis system (Bio-Rad), at $200 \mathrm{~V}$ for $2 \mathrm{~h}$. Before electrophoresis, samples were mixed 1:1 with $2 \times$ sample buffer and heated at $100^{\circ} \mathrm{C}$ for $10 \mathrm{~min}$. The Buhl strain of IPNV and non-infected CHSE-214 and EPC cells were included as controls. Polypeptide bands were detected by Coomassie blue staining.

Western blot analysis. Following SDS-PAGE, proteins were transferred to $0.45 \mathrm{~mm}$ nitrocellulose sheets (Bio-Rad) at $80 \mathrm{~V}$ for $90 \mathrm{~min}$ at $4{ }^{\circ} \mathrm{C}$, using the buffer system described by Towbin et al. (1979). Western blot analysis was performed using a polyclonal antibody against IPNV obtained from rabbit. The membranes were blocked for $1 \mathrm{~h}$ in a solution of $10 \%$ milk in PBS at $37^{\circ} \mathrm{C}$, washed 3 times (20 min each) with PBS-Tween $20(0.05 \%)$, and reacted with antiserum that was diluted 1:1000 in PBS at room temperature for $2 \mathrm{~h}$ on a slow-speed flat-bed orbital shaker. The membranes were washed and then incubated for $1 \mathrm{~h}$ at room temperature with anti-rabbit appropriate secondary antibody conjugated to alkaline phosphatase (Anti-rabbit Ig G:AP, adsorbed with Human Ig G; Stressgen) diluted 1:1000 with PBS-Tween $20(0.05 \%)$. After washing, the membranes were developed with an AP conjugate substrate (Bio-Rad) at room temperature for 5 to 20 min

CsCl density gradient centrifugation. Fluids from CHSE-214 cell cultures exhibiting CPE were collected and centrifuged for $30 \mathrm{~min}$ at $3000 \times g$. The supernatant was ultracentrifuged for $90 \mathrm{~min}$ at $90000 \times g$, and the pellets resupended in $500 \mathrm{ml}$ Hanks' balanced salt solution and sonicated for $30 \mathrm{sec}$ at $20 \mathrm{Kcal}$. The samples were placed on the top of a discontinuous $\mathrm{CsCl}$ gradient: 40,30 and $20 \%$ $\mathrm{CsCl}$ in $1 \times \mathrm{SSC}$, and centrifuged at $115000 \times g$ for $22 \mathrm{~h}$ at $4^{\circ} \mathrm{C}$ in a swinging bucket rotor (Beckman SW 50.1). Virus bands were readily located by light scattering and collected from each gradient separately. The refractive indices were measured using a refractometer (Bausch \& Lomb) and the density computed from tables. These fractions were then ultracentrifuged in a Beckman TLA 45 rotor at $125000 \times g$ for $1 \mathrm{~h}$ at $4^{\circ} \mathrm{C}$. The pellets were resuspended in $100 \mathrm{ml}$ of sample buffer $(1 \mathrm{M} \mathrm{NaCl}, 20 \mathrm{mM}$ Tris- $\mathrm{HCl}$, 5 mM EDTA) and analyzed by electron microscopy and by SDS-PAGE.

Electron microscopy (EM). In total, $20 \mu \mathrm{l}$ of the resuspended pellets were adsorbed to parlodionfilmed, carbon-coated 400 mesh copper grids. The adsorbed material was then stained with $2 \%(\mathrm{w} / \mathrm{v})$ phosphotungstic acid ( $\mathrm{pH}$ 6.09) and visualized by transmission electron microscopy (TEM, Philips CM 12). Immunogold EM was performed by the method of Novoa (1996), using IPNV-specific antiserum as above.

\section{RESULTS}

\section{Identification of the viral isolates by RT-PCR}

All of the isolates were confirmed to be aquatic birnaviruses by means of RT-PCR using the Pr D primer pairs, which yielded amplification products of the expected size of approximately 174 bp (Fig. 2).

\section{Nucleotide sequences and phylogenetic analysis}

Alignment of the sequences of the $174 \mathrm{bp}$ fragment of the NS gene obtained by PCR amplification using primer set Pr D showed that the sequences were identical among the isolates and with published sequences of the same region of the NS gene of the Dry Mills (DM) and WB reference strains.

On the basis of these initial results, and in order to detect minor differences among the new isolates, a larger fragment of $600 \mathrm{bp}$, corresponding to most of the NS gene, was amplified by nested RT-PCR using primer sets $\mathrm{Pr} \mathrm{IB}$, and sequenced (GenBank accession numbers: AY542856 to AY542863). Of the new isolates, only one, isolate 9R3, showed a minor difference (1 nucleotide per $600 \mathrm{bp}$ ) from the remaining isolates, which were identical to each other and to the reference strain DM over this larger region of the NS gene.

For analysis of a region of the VP2 gene, a $428 \mathrm{bp}$ fragment was amplified and the sequence of a $370 \mathrm{bp}$ internal region was compared (GenBank accession numbers: AY542851 to AY542855). The analysis of

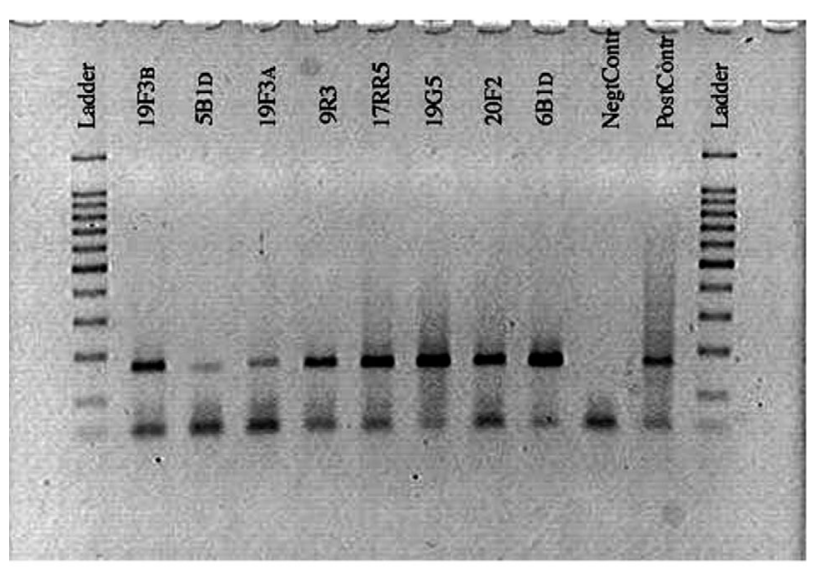

Fig. 2. Identification of the FC isolates by RT-PCR, employing the primer set Pr D. The amplification product showed the expected size around 174 bp. NegtContr: negative control (distilled water as template for PCR). PostContr: positive control (genome of IPNV WB as template for PCR). Ladder: molecular weight markers (100 DNA Ladder, Invitrogen; from bottom to top: 50, 100, 200, 300, 400, 500, 600, 700, 800, 900,1000 , and $1500 \mathrm{bp}$ ) 


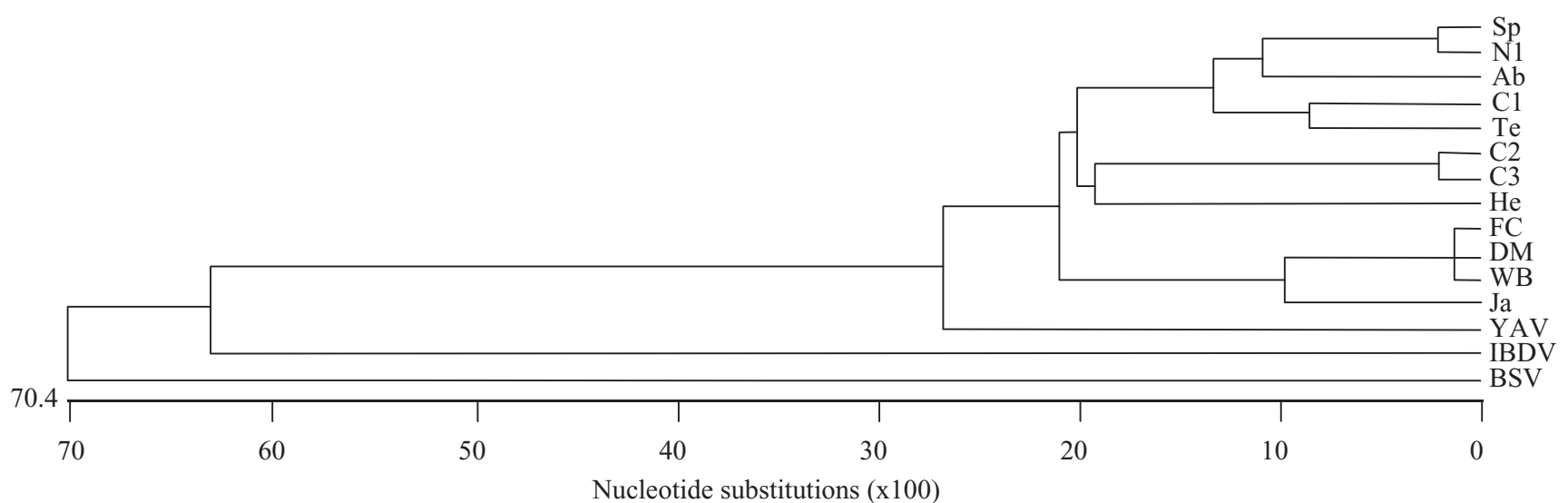

Fig. 3. Phylogenetic tree, based on the analysis of a $389 \mathrm{nt}$ region, that encodes a portion of the VP2 protein, showing the relationship between our isolates (represented by FC) and the main serotypes of IPNV. YAV, BSV and IBDV were used as outgroups. The nucleotide sequence accession numbers are: AF343571 (DM); AF342727 (WB); M18049 (Ja); AF342728 (Sp); L40580 (Ab); AF342730 (He); AF342731 (Te); AF342732 (C1); L40581 (C2); AF342734 (C3); D0071 (N1); ABO11440 (YAV); AJ459382 (BSV); NC004178 (IBDV)

sequence pair distances (data not shown) indicates that the 9R3 isolate had a $100 \%$ nucleotide identity with the DM isolate, and $99.4 \%$ with the WB isolate. Lower percentages were obtained with the published sequences of the remaining IPNV reference strains. The 19G5 isolate (as representative of the isolates showing a $100 \%$ nucleotide sequence identity with DM in the NS gene) showed a slightly lower identity with DM $(99.7 \%)$ and WB $(99.2 \%)$. In terms of amino acid sequences all the new isolates were identical to the homologous region of the DM strain and 99.2\% identical to WB. The phylogenetic tree, based on the nucleotide sequence of this fragment of the hypervariable region of VP2 (Fig. 3), showed that the FC isolates and the WB-type reference strains belong to the same cluster. The Jasper isolate was the next most closely related strain to our isolates. Isolates representing the remaining serotypes showed a much lower relationship to the FC isolates. As expected IBDV, YAV and BSV were widely separated from the other isolates analyzed.

\section{Nucleic acid and protein analysis}

When viral genomic RNA segments were analyzed by polyacrylamide gel electrophoresis, all the FC'99 isolates appeared identical, showing an extremely narrow profile (Fig. 4). The larger genome segment (A) had an estimated molecular weight of $2.06 \mathrm{MDa}$ and the smaller genome segment (B) of $1.93 \mathrm{MDa}$. The pattern formed by the genome segments did not correspond with any of the reference strains of IPNV included in this study.

A total of 4 viral proteins having approximate molecular weights of 90,50, 25 and 20 KDa could be distinguished from normal cellular proteins in polyacrylamide gels (Fig. 5A). No differences were detected among the protein profiles of the isolates when concentrated crude virus from CHSE-214 infected cells was used. On the contrary, when EPC cells were infected, only isolates $19 \mathrm{~F} 3_{\mathrm{B}}$ and $17 \mathrm{R} 5$ showed the typical 4-band pattern (Fig. 5B).

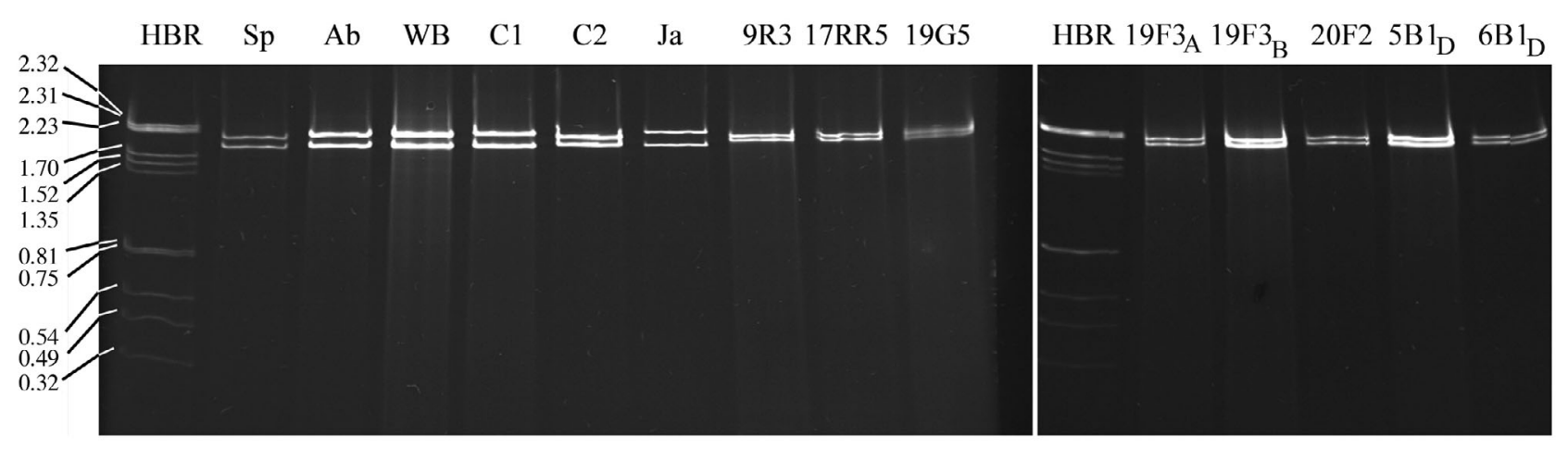

Fig. 4. Comparison of RNA patterns of FC'99 birnavirus isolates in 7.5\% SDS-PAGE. RNA segments of the aquareovirus HBR (Dopazo et al. 1992) were included as molecular weight markers (data expressed as MDa) 

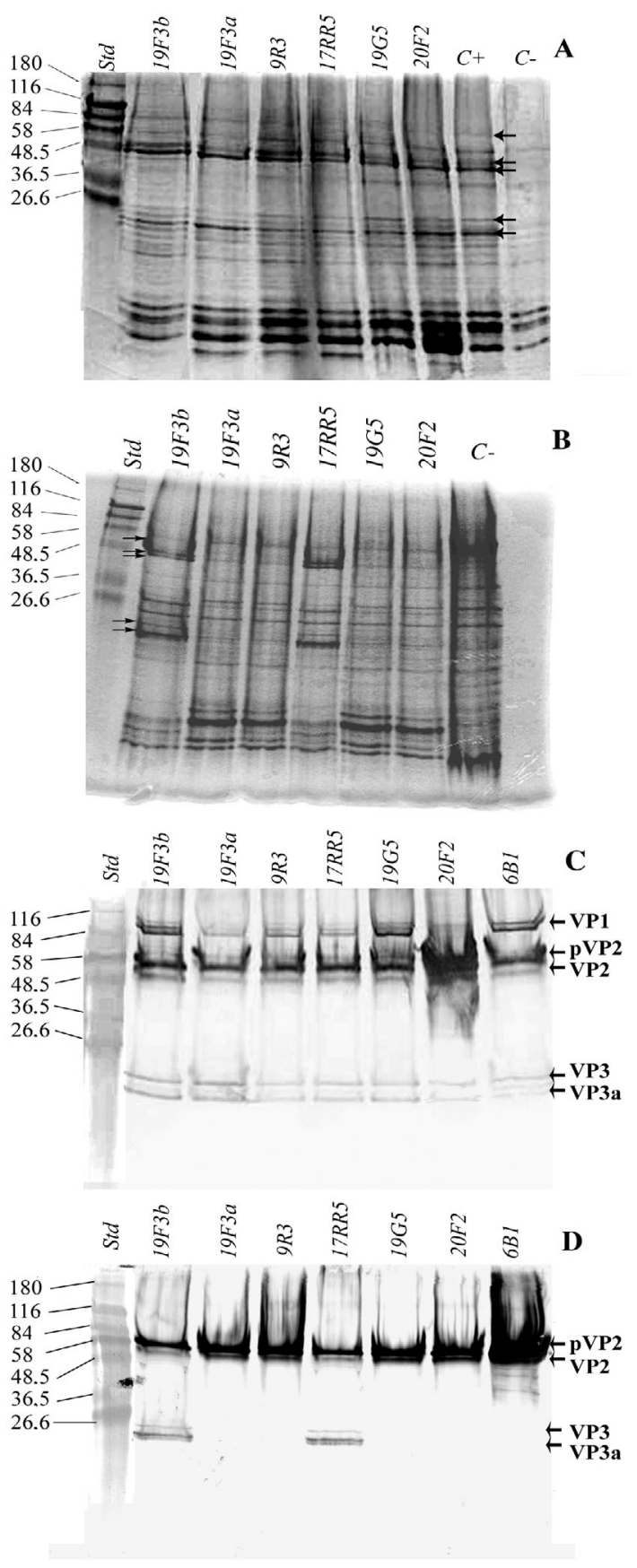

Fig. 5. Protein content of viral isolates. (A) Protein profile of viruses concentrated from CHSE-214 infected cells (C+: positive control, corresponding to the protein profile of the reference strain Buhl concentrated from CHSE-214 infected cells; $\mathrm{C}-$ : negative control, consisting of protein profile from noninfected CHSE-214 cells), and (B) protein profile of viruses concentrated from EPC infected cells; both gels were stained with Coomassie blue ( $\mathrm{C}-$ : negative control, consisting of noninfected EPC cells). (C) Western blot assay applied to viral proteins obtained from CHSE-214 infected cells; (D) Western blot assay applied to viral proteins obtained from EPC infected cells. (Std: molecular weight markers shown in $\mathrm{kDa}$ ) Arrows label the position of proteins VP1, pVP2, VP2, VP3 and VP3a (from top to bottom)
Western blot assays confirmed the viral origin of the proteins from CHSE-214 infected cells by reaction with anti-IPNV polyclonal antiserum (Fig. 5C). Western blots of proteins from EPC infected cells (Fig. 5D) revealed that, whereas the VP3 and VP3a viral proteins were present only in strains $19 \mathrm{~F} 3_{\mathrm{B}}$ and $17 \mathrm{R} 5$, pVP2 and VP2 were detected in all the isolates and VP1 was not detected in any isolate. No reaction with the antiserum was observed with CHSE-214 and EPC non-infected cells (data not shown).

\section{Buoyant density and EM}

Electron microscopy of the viruses concentrated from infected CHSE-214 cells revealed the presence of icosahedral particles with a diameter of approximately $60 \mathrm{~nm}$ (Fig. 6A). In these preparations, a low proportion of tubular structures with a diameter of approximately $55 \mathrm{~nm}$, a length of up to $2 \mu \mathrm{m}$, and appearing to have a helical-like symmetry were also visualized. When the isolates were propagated in EPC cells, most showed the same results by EM, and only isolates $19 \mathrm{~F} 3_{\mathrm{B}}$ and 17R5 showed a high proportion of rigid tubules (Fig. 6C). The tubular structures were demonstrated to react with IPNV-specific antiserum by immunogold staining (Fig. 6E).

Bands of 2 different densities were obtained in $\mathrm{CsCl}$ gradients. When viral samples were not subjected to cloning by serial dilution, a visible band corresponding to a density of approximately $1.32 \mathrm{~g} \mathrm{~cm}^{-3}$ was obtained. Visualization of the virus concentrated from this band revealed the presence of typical icosahedral birnaviruslike particles, and only occasionally were tubular structures observed (Fig. 6B). After cloning, 2 bands were obtained, one having the same density as described above, and another having a density in $\mathrm{CsCl}$ of approximately $1.30 \mathrm{~g} \mathrm{~cm}^{-3}$ in which a high proportion of tubular structures was observed by EM (Fig. 6D).

Analysis of the protein content of the virus in the fractions collected from the 2 bands was carried out by SDS-PAGE. As shown in Fig. 7, the material from the band having a density of $1.32 \mathrm{gcm}^{-3}$ showed the typical IPNV 4-band polypeptide profile with some additional contaminating cellular proteins, as demonstrated in Western blot gels. However, when the $1.30 \mathrm{~g} \mathrm{~cm}^{-3} \mathrm{CsCl}$ band was analyzed, only pVP2 and VP2 were seen.

\section{DISCUSSION}

Aquatic birnaviruses have a wide host range, infecting many species of fish. Although mainly known as agents affecting farmed salmonids, IPNV and IPNVlike viruses have also been isolated from wild fishes 

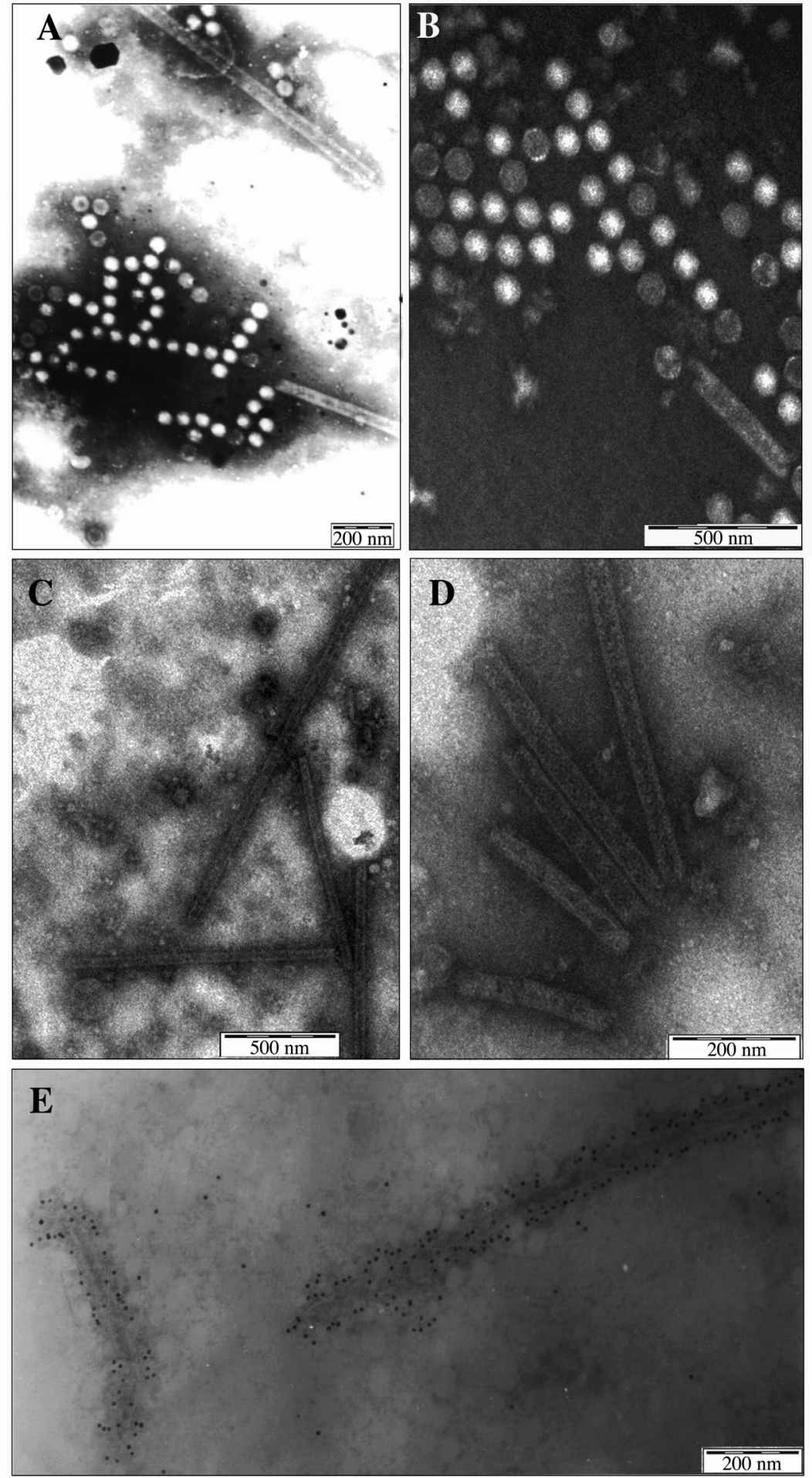

Fig. 6. Electron microscopy of birnavirus isolates. (A) Isolate 9R3 concentrated from CHSE-214 infected cells, showing a majority of icosahedral particles. (B) Isolate $17 \mathrm{R} 5$ after cloning by serial dilutions: sub-clone with a density in $\mathrm{CsCl}$ of around $1.32 \mathrm{~g} \mathrm{~cm}^{-3}$, showing a majority of icosahedral particles. (C) Isolate 17R5 concentrated from EPC infected cells, showing a majority of tubular structures. (D) Isolate 17R5 after cloning by serial dilutions: sub-clone with a density in $\mathrm{CsCl}$ of around $1.30 \mathrm{~g} \mathrm{~cm}^{-3}$. (E) Tubular structures labeled by immunogold using anti-IPNV specific antisera
(Hill 1982, Ahne 1985, Wolf 1988). The first isolation of IPNV from feral fish was reported by Sonstergard et al. (1972), who recovered IPNV from asymptomatic white suckers (Catastomus commersoni). Munro et al. (1976) reported the detection of IPNV among wild fish in Loch Awe and the virus was also reported from asymptomatic wild Arctic char (Salvelinus alpinus) by Souter et al. (1984). Until the 1990s, IPNV was isolated from only a few marine species: Atlantic menhaden (Brevoortia tyrannnus) in Maryland, USA (Stephens et al. 1980); Southern flounder (Paralichthys lethostigma) in North Carolina, USA (Helms 1981, McAllister et al. 1983); and wild yellowtail (Seriola quinqueradiata) in Tosa Bay, Japan (Isshiki et al. 1989, Hosono et al. 1996). In 1998, birnaviruses were isolated from cod and herring in the United Kingdom (ICES 1998). In 1999, Mortensen et al. reported the isolation of aquatic birnaviruses from flounder (Platichyhys flesus) and dab (Limanda limanda) from the marine waters surrounding Denmark. The most recent isolations of aquatic birnaviruses from marine species have been from wild flounder (Rhombosolea tapirina), cod (Pseudophycis sp.), spiked dogfish (Squalus megalops) and ling (Genypterus blacodes) during routine sampling in Australia (Crane et al. 2000), and from flounder (Paralichthys olivaceus), Japanese horse mackered (Trachurus japonicus) and dark banded rockfish (Sebastes inermes) in Japan (Watanabe et al. 2002). The isolations from marine fish seem to constitute a separate genogroup, as recently demonstrated (Zhang \& Suzuki 2003).

Our laboratory, in collaboration with the Instituto de Investigacións Mariñas (CSIC) and the Instituto Español de Oceanografía (IEO) (Vigo, Spain), has participated in 2 research campaigns carried out at the Flemish Cap, a fishery located in international waters, close to the Canadian Atlantic coast, and where fishing is regulated by the Northwest Atlantic Fisheries Organization (NAFO). From these studies, both birnaviruses and viral hemorrhagic sep- 


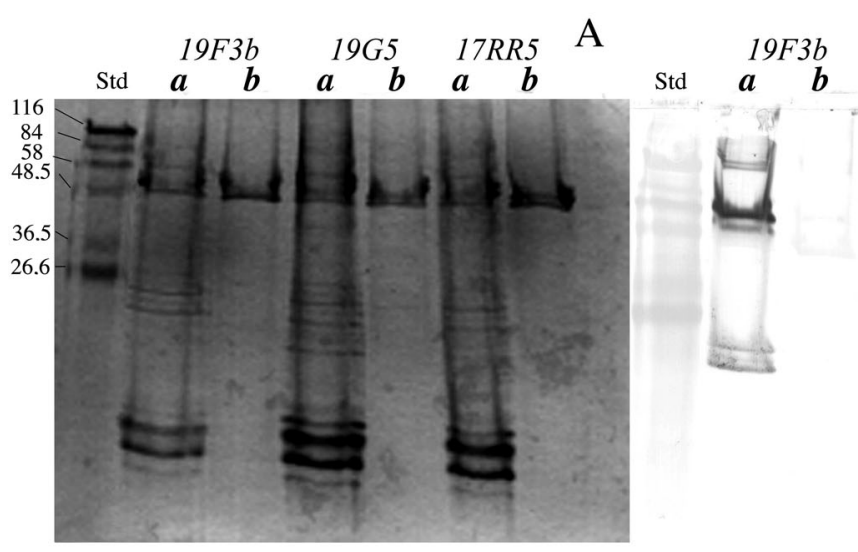

ticemia virus (VHSV) have been isolated from different species of wild fish (Bandín et al. 1997, Dopazo et al, 2002). In the first campaign at the Flemish Cap in 1994 (FC'94), IPNV-like viruses were isolated from Atlantic cod (Gadus morhua), Greenland halibut (Reinhardtius hippoglossoides), American plaice (Hippoglossoides platessoides) and witch flounder (Glyptocephalus cynoglossus) (Bandín et al. 1997). From the 1999 campaign, viruses having the typical birnavirus morphology were isolated (Romero-Brey et al. 2002) and their identity confirmed by RT-PCR in the present study.

Results from nucleotide sequencing demonstrated that the FC isolates were closely related or identical to each other. The new isolates were also closely related to the American reference strains DM and WB (representing serotype A1), both originally isolated from trout in Maine, USA (Leintz \& Springer 1973). This result was likely due to the geographic proximity of the Flemish Cap fishery to the Atlantic coast of the USA. In addition, it indicates a clear relatedness between IPNV isolates from aquaculture settings and from wild marine populations as reported for other fish viruses (Stone et al. 1997, Dixon 1999).

Interestingly, when the electropherotypes (EFT) of the viral genome segments of the FC isolates were analyzed, no similarity to any of the reference strains used was observed. Nevertheless, comparison with the electropherogroups (EGs) described by Cutrín et al. (2000) suggests the narrow pattern obtained for the FC isolates best corresponds to isolate EG6 related to the Ja strain. This does not agree with the results we obtained from sequence analysis, and Cutrín et al. (2003) have recently reported that the use of EFTs is not advised for typing of aquatic birnaviruses, as the results are not consistent with those obtained from serotyping, restriction fragment length polymorphism (RFLP), or sequencing.

The proteins in concentrated virus preparations were typical of IPNV-type proteins in their sizes and electrophoretic pattern. Moreover, they reacted with

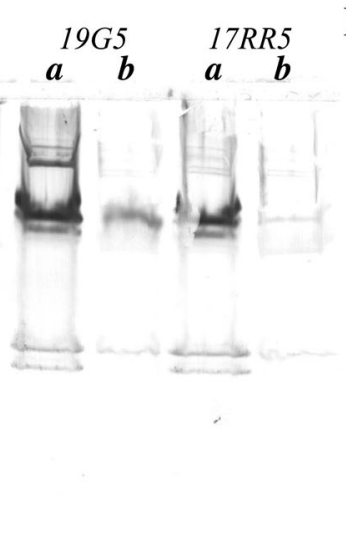

B

Fig. 7. SDS-PAGE gel showing the protein content of the viral particles constituting the fractions corresponding to densities $1.32 \mathrm{~g} \mathrm{~cm}^{-3}$ (lanes a) and $1.30 \mathrm{~g}$ $\mathrm{cm}^{-3}$ (lanes b) in $\mathrm{CsCl}$ gradient centrifugation. (A) Coomassie blue stained gel, (B) Western blot assay the anti-IPNV polyclonal antiserum in Western blots, further confirming the identity of the isolates. It was interesting that 2 distinct protein patterns were obtained for the different isolates when the viruses were cultured in EPC cells. Electron microscopy showed the presence of a high proportion of tubular structures in the preparations of those isolates having only the pVP2 and VP2 type proteins. This result suggested the approach of cloning of selected strains by serial dilution and attempting to separate the tubular structures from the typical IPNV-icosahedral particles. This strategy enabled us to discover 2 important features of the tubules: (1) they have slightly lower density $\left(1.30 \mathrm{~g} \mathrm{~cm}^{-3}\right)$ than icosahedral particles

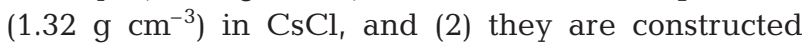
principally (or exclusively) from pVP2 and VP2-type proteins. Because cloning could never eliminate the icosahedral particles, presence of the tubules appeared to be strictly dependent upon the presence of the complete birnavirus particles.

The shape and size of the tubules we observed resembled those described in other aquatic birnaviruses (Moss \& Gravell 1969, Kudo et al. 1975, Novoa 1996, Espinoza et al. 2000). Similar structures have also been detected, and extensively studied, in infectious bursal disease virus (IBDV), a birnavirus from the genus Avibirnavirus (Granzow et al. 1997b). In this sense, the tubules described in the present report would be similar to those termed type I tubules by Granzow et al. (1997a) in IBDV, and Espinoza et al. (2000) in IPNV. Those tubules would be constructed exclusively from a precursor of the VP2 viral protein (Martínez-Torrecuadrada et al. 2000), probably due to a lack of maturation of the pVP2 form to the VP2 (Chevalier et al. 2002). However, the results from the present study indicate that both forms of that protein are incorporated in construction of the tubules.

Some authors have suggested that the VP3 would act as a scaffolding protein, which would be essential for the 'closing' of the tubular structures into icosahedral 
capsids, as well as for the maturation of pVP2 into VP2 (Martínez-Torrecuadrada et al. 2000, Chevalier et al. 2002). Considering that the tubules can be propagated in cell culture but cannot be completely separated from the IPNV-typical icosahedral forms by cloning and that cloning appeared to enhance the ratio of tubular structures in selected preparations, it may be possible that many of the virus particles in preparations having a high proportion of tubular structures contain some kind of mutation resulting in a failure to produce an active VP3 polypeptide.

Whether or not a mutation in the genome is the mechanism to explain the generation of the tubules is under research at present, and will be the subject of a further report.

Acknowledgements. Inés Romero Brey thanks Julia Franke and people from the Western Fisheries Research Center (WFRC), Seattle, USA, for their helpful support during her stay there. This work was supported by grants MAR99-0637C02-01 from Comisión Interministerial de Ciencia y Tecnología (DGSIC), ACU01-010/2001/PC159 from Ministerio de Ciencia y Tecnología, and PGIDIT02BTF23501PR from the Secretaría Xeral de I+D, Xunta de Galicia. This is Scientific Contribution no. 001/2003 of the Instituto de Acuicultura.

\section{LITERATURE CITED}

Ahne W (1985) Virusinfektion bei Fischen: ätiologie, diagnose und bekämpfung. Zbl Vet Med B 32: 237-264

Bandín I, Silva A, Olveira JG, Cutrín JM, Dopazo CP, Barja JL (1997) Virus in marine wild fish. In: Proc VIIIth Int Conf Dis Fish and Shellfish, Sep 14-19, Edinburgh. European Association of Fish Pathologists, p 1

Blake SL, Schill WB, McAllister PE, Lee MK, Singer JT, Nicholson BL (1995) Detection and identification of aquatic birnaviruses by PCR assay. J Clin Microbiol 33: 835-839

Blake SL, Ma JY, Caporale DA, Jairath S, Nicholson BL (2001) Phylogenetic relationships of aquatic birnaviruses based on deduced amino acid sequences of genome segment A cDNA. Dis Aquat Org 45:89-102

Caswell-Reno P, Lipipun V, Reno PW, Nicholson BL (1989) Utilization of a group-reactive and other monoclonal antibodies in an enzyme immunodot assay for identification and presumptive serotyping of aquatic birnaviruses. J Clin Microbiol 27:1924-1929

Chevalier C, Lepault J, Erk I, Da Costa B, Delmas B (2002) The maturation process of pVP2 requires assembly of infectious bursal disease virus capsids. J Virol 76: $2384-2392$

Christie KE, Ness S, Djupvik HO (1990) Infectious pancreatic necrosis in Norway; partial serotyping by monoclonal antibodies. J Fish Dis 13:323-327

Crane MSJ, Hardy-Smith P, Williams LM, Hyatt AD and 5 others (2000) First isolation of an aquatic birnavirus from farmed and wild fish species in Australia. Dis Aquat Org 43:1-14

Cutrín JM, Olveira FG, Barja JL, Dopazo CP (2000) Diversity of infectious pancreatic necrosis virus strains isolated from fish, shellfish and reservoirs in Northwestern Spain. Appl Environ Microbiol 66:839-843

Cutrín JM, Barja JL, Nicholson BL, Blake S, Dopazo CP (2004)
Restriction fragment length polymorphisms (RFLP`s) and sequence analysis: an approach for genotyping IPNV reference strains and other aquabirnaviruses isolated from Northwestern Spain. Appl Environ Microbiol 10:1059-1067

Dixon PF (1999) VHSV came from the marine environment: clues from the literature, or just red herrings? Bull Eur Assoc Fish Pathol 19:60-65

Dobos P (1976) Size and structure of the genome of the infectious pancreatic necrosis virus. Nucleic Acids Res 3: 1903-1919

Dobos P (1995) The molecular biology of infectious pancreatic necrosis virus (IPNV). Annu Rev Fish Dis 5:25-54

Dobos P, Hill BJ, Hallett R, Kells DTC, Becht H, Teninges D (1979) Biophysical and biochemical characterization of 5 animal viruses with bisegmented double-stranded RNA genomes. J Virol 32:593-605

Dopazo CP, Toranzo AE, Roberson BS, Baya A, Hetrick FM (1992) Antigenic relationships among rotaviruses isolated from fish. J Fish Dis 15:27-36

Dopazo CP, Bandín I, López-Vazquez C, Lamas L, Noya M, Barja JL (2002) Isolation of viral hemorrhagic septicemia virus from Greenland halibut Reinhardtius hippoglossoides caught in the Flemish Cap. Dis Aquat Org 50: 171-179

Duncan R, Dobos P (1986) The nucleotide sequence of infectious pancreatic necrosis virus (IPNV) dsRNA segment A reveals one large ORF encoding a precursor polyprotein. Nucleic Acids Res 14: 5934

Duncan R, Nagy E, Krell PJ, Dobos P (1987) Synthesis of the infectious pancreatic necrosis virus polyprotein, detection of a virus-encoded protease, and fine structure mapping of genome segment A coding regions. J Virol 61:3655-3664

Espinoza JC, Hjalmarsson A, Everitt E, Kuznar J (2000) Temporal and subcellular localization of infectious pancreatic necrosis virus structural proteins. Arch Virol 145:739-748

Granzow H, Birghan C, Mettenleiter TC, Beyer J, Köllner B, Mundt E (1997a) A second form of infectious bursal disease virus-associated tubule contains VP4. Virology 8879-8885

Granzow H, Weiland F, Fichtner D, Enzmann PJ (1997b) Studies on the ultrastructure and morphogenesis of fish pathogenic viruses grown in cell culture. J Fish Dis 20: $1-10$

Håvarstein LS, Kalland KH, Christie KE, Endresen C (1990) Sequence of the large double-stranded RNA segment of the N1 strain of infectious pancreatic necrosis virus: a comparison with other Birnaviridae. J Gen Virol 71: 299-308

Helms RF (1981) Pamlico River flounder fish kill (an investigation). North Carolina Dept Nat Resour Commun Develop p. 1-28

Hill BJ (1982) Infectious pancreatic necrosis virus and its virulence. In: R. J. Roberts (ed) Microbial disease of fish. Academic Press, London, p 91-114

Hill J, Way K (1995) Serological classification of infectious pancreatic necrosis (IPN) virus and other aquatic Birnaviruses. Annu Rev Fish Dis 5:55-77

Hjalmarsson A, Carlemalm E, Everitt E (1999) Infectious pancreatic necrosis virus: identification of a VP3-containing ribonucleoprotein core structure and evidence for Olinked glycosilation of the capsid protein VP2. J Virol 73: $3484-3490$

Hong JR, Gong HY, Wu JL (2002) IPNV VP5, a novel antiapoptosis gene of the Bcl-2 family, regulates Mcl-1 and viral protein expression. Virology 295:217-229

Hosono N, Suzuki S, Kusuda R (1996) Genogrouping of bir- 
naviruses isolated from marine fish: A comparison of VP2/NS regions on genome segment A. J Fish Dis 19: 295-302

Huang C, Chien MS, Landolt M, Batts B, Winton JR (1996) Mapping the neutralizing epitopes on the glycoprotein of infectious haematopoietic necrosis virus, a fish rabdovirus. J Gen Virol 77:3033-3040

Huang MTF, Manning DS, Warner M, Stephens EB, Leong JC (1986) A physical map of the viral genome for infectious pancreatic necrosis virus $\mathrm{Sp}$ : analysis of cell-free translation products derived from viral cDNA clones. J Virol 60: 1002-1011

ICES (1998) Report of the working group on pathology and diseases of marine organisms. Gdyna Poland March 3-7 1998. ICES CM 1997/F:7

Isshiki T, Kawai K, Kusuda R (1989) Incidence of yellowtail ascites virus (YAV) in wild yellowtail fingerling. Nippon Suissan Gakkaishi 55:633-637

Kudo S, Kurosaya D, Kunimine I, Nobusawa K, Kobayashi S (1975) Ultracytochemical observations on the ultrastructure of infectious pancreatic necrosis (IPN) virus. Jap J Ichthyol 21:203-212

Laemmli UK (1970) Cleavage of structural proteins during assembly of the head of bacteriophage T4. Nature 227 , 680-685

Lannan CN, Winton JR, Fryer JL (1984) Fish cell lines: establishment and characterization of nine cell lines from salmonids. In Vitro [In Vitro] 20:107-114

Leintz JC, Springer J (1973) Neutralization test of IPNV with polyvalent antiserum. J Wildl Dis 9:120-124

Magyar G, Dobos P (1994) Evidence for the detection of the infectious pancreatic necrosis virus polyprotein and the $17-\mathrm{kDa}$ polypeptide in infected cells and of the NS protease in purified virus. Virology 204:580-589

Manning DS, Leong JC (1990) Expression in Escherichia coli of the large genomic segment of infectious pancreatic necrosis virus. Virology 179:16-25

Martínez-Torrecuadrada JL, Caston JR, Castro M, Carrascosa JL, Rodríguez JF, Casal J (2000) Different architectures in the assembly of infectious bursal disease virus capsid proteins. Virology 278:322-331

McAllister PE, Newman MW, Sauber JH, Owens WJ (1983) Infectious pancreatic necrosis virus: isolation from Southern flounder, Paralichthys lethostigma, during an epizootic. Bull Eur Assoc Fish Pathol 3:37-38

McAllister PE, Owens WJ, Ruppenthal TM (1987) Detection of infectious pancreatic necrosis virus in pelleted cell and particulate components from ovarian fluid of brook trout (Salvelinus fontinalis). Dis Aquat Org 2:235-237

Mortensen HF, Heue OE, Lorenzen N, Otte L, Olensen NJ (1999) Isolation of viral haemorrhagic septicemia virus (VHSV) from wild marine fish species in the Baltic Sea, Kattegat, Skagerrak and the North Sea. Virus Res 63: 95-106

Moss LH, Gravell M (1969) Ultrastructural and sequential development of infectious pancreatic necrosis virus. J Virol 3:52-58

Müller H, Scholtissek C, Becht H (1979) The genome of infectious bursal disease virus consists of two segments of doubled stranded RNA. J Virol 44:384-392

Munro ASL, Liversidge J, Elson KGR (1976) The distribution and prevalence of infectious pancreatic necrosis virus in wild fish in Loch Awe. Proc R Soc Edinb (B) (Nat. Environ.) 75:223-232

Nagy E, Duncan R, Krell P, Dobos P (1987) Mapping of the large RNA genome segment of infectious pancreatic necrosis virus by hybrid arrested translation. Virology 158 : 211-217

Nicholson BL (1993) Use of monoclonal antibodies in identification and characterization of fish disease. In: F. Hetrick and M. Faisal (eds) Annu rev fish dis. Pergamon Press, New York, p 241-257

Novoa B (1996) Immunogold technique applied to electron microscopy of infectious pancreatic necrosis virus (IPNV). Fish Pathol 31:141-143

Özel M, Gelderblom H (1985) Capsid symmetry of viruses of the proposed birnavirus group. Arch Virol 84:149-161

Romero-Brey I, Bandín I, Dopazo CP, López-Vázquez C, Silva A, Barja JL (2002) What viruses can be found in wild fish? A preliminary study. In: Proc 5th Int Symp Viruses of Lower Vertebrates, Aug 27-30, Seattle, p 48

Schwanz-Pfitzner I, Özel M, Darai G, Gelderblom H (1984) Morphogenesis and fine structure of eel virus (Berlin), a member of the proposed birnavirus group. Arch Virol 81: 151-162

Sonstergard RA, McDermott LA, Sonstergard KS (1972) Isolation of infectious pancreatic necrosis virus from white suckers (Catostomus commersoni). Nature 236:174-175

Souter BW, Dwilow AG, Knight K (1984) Infectious pancreatic necrosis virus: isolation from asymptomatic wild Arctic char (Salvelinus alpinus L.). J Wildl Dis 20: 338-339

Stephens EB, Newman MW, Zacjary AL, Hetrick FM (1980) A viral aetiology for the annual spring epizooties of Atlantic menhaden Brevoortia tyrannus (Latrobe) in Chesapeake Bay. J Fish Dis 3:387-398

Stone DM, Way K, Dixon PF (1997) Nucleotide sequence of the glycoprotein gene of viral haemorrhagic septicaemia (VHS) viruses from different geographical areas: a link between VHS in farmed fish species and viruses isolated from North Sea cod (Gadus morhua L.). J Gen Virol 78: $1319-1326$

Teninges D, Ohanessian A, Richard-Molard C, Contamine D (1979) Isolation and biological properties of Drosophila X virus. J Gen Virol 42:241-254

Towbin H, Staehelin T, Gordon J (1979) Electrophoresis transfer of proteins from polyacrylamide gels to nitrocellulose sheets: procedure and some applications. Proc Natl Acad Sci USA 76:4350-4354

van Regenmortel MHV, Fauquet CM, Bishop HL, Carstens EB and 7 others (2000) Virus taxonomy. In: 7th Report of the International Committee on Taxonomy of Viruses. Academic Press, New York, NY

Watanabe L, Pakingking R, Iida H, Nishizawa T, Yoshisuke I, Arimoto M, Muroga K (2002) Isolation of aquabirnavirus and viral hemorrhagic septicemia virus (VHSV) from wild marine fishes. Fish Pathol 37:189-191

Wolf K (1988) Fish viruses and fish viral diseases. Cornell University Press, Ithaca, NY

Zhang CX, Suzuki S (2003) Comparison of the RNA polymerase genes of marine birnavirus strains and other birnaviruses. Arch Virol 148:745-758

Submitted: February 19, 2004; Accepted: April 22, 2004

Proofs received from author(s): September 7, 2004
Editorial responsibility: Jo-Ann Leong,

Kaneohe, Hawaii, USA 